\title{
Nie tylko Pinokio. Dwa głosy o włoskiej literaturze dziecięcej i młodzieżowej na polskim rynku wydawniczym
}

\author{
Biernacka-Licznar, K. (2018). Serce Pinokia. Włoska literatura \\ dla dzieci i młodzieży w Polsce w latach 1945-1989. Warszawa: \\ Wydawnictwo Naukowe i Edukacyjne SBP.
}

Ożóg-Winiarska, Z. (2017). Włoska literatura dla dzieci i młodzieży w zbliżeniach polskich. Kielce: Instytut Filologii Polskiej UJK.

\section{Abstrakt:}

$\mathrm{W}$ artykule recenzyjnym poddano analizie dwie publikacje dotyczące recepcji włoskiej literatury dla dzieci i młodzieży na polskim rynku wydawniczym w XX i XXI wieku. Pierwsza z nich - Serce Pinokia. Włoska literatura dla dzieci i młodzieży w Polsce w latach 1945-1989 autorstwa Katarzyny Biernackiej-Licznar (2018) - systematyzuje i porządkuje zjawiska dotyczące recepcji włoskiej literatury dla dzieci i młodzieży na tle dynamicznych zmian politycznych w Polsce w tytułowym okresie. Druga rozprawa - Włoska literatura dla dzieci i młodzieży w zbliżeniach polskich autorstwa Zofii Ożóg-Winiarskiej (2017) - jest krytycznoliterackim opracowaniem poświęconym współczesnej literaturze włoskiej dla młodych odbiorców, w którym podkreślono przede wszystkim wartości estetyczne owego piśmiennictwa oraz jego złożony, wielowymiarowy charakter.

Słowa kluczowe:

cenzura, Katarzyna Biernacka-Licznar, literatura dziecięca i młodzieżowa, literatura włoska, Polska, Polska Rzeczpospolita Ludowa, Włochy, Zofia Ożóg-Winiarska

* Dorota Rejter - mgr, przygotowuje rozprawę doktorską na wydziale „Artes Liberales" Uniwersytetu Warszawskiego dotyczącą mitologicznych postaci kobiecych we współczesnej włoskiej literaturze dla dzieci i młodzieży. Kontakt: dorota.bazylczyk@ student.uw.edu.pl. 


\title{
Not only Pinocchio: A Double Voice on Italian Children's and Young Adult Literature on the Polish Publishing Market
}

\author{
Biernacka-Licznar, K. (2018). Serce Pinokia. Włoska literatura dla dzieci \\ i młodzieży w Polsce w latach 1945-1989. Warszawa: Wydawnictwo Naukowe \\ i Edukacyjne SBP.
}

Ożóg-Winiarska, Z. (2017). Włoska literatura dla dzieci i młodzieży w zbliżeniach polskich. Kielce: Instytut Filologii Polskiej UJK.

\section{Abstract:}

In this review article, two publications devoted to the reception of Italian children's and young adult literature on the Polish publishing market in the $20^{\text {th }}$ and $21^{\text {st }}$ centuries are analysed. The first one - Serce Pinokia. Włoska literatura dla dzieci $i$ młodzieży w Polsce w latach 1945-1989 [Pinocchio's Heart: Italian Literature for Children and Young Adults in Poland, 1945-1989] by Katarzyna Biernacka-Licznar (2018) - systematises and organises the phenomena concerning the reception of Italian literature for children and youth against the background of dynamic political changes in Poland during the titular period. The second dissertation - Włoska literatura dla dzieci i młodzieży w zbliżeniach polskich [Italian Literature for Children and Young Adults in Polish Close-ups] by Zofia Ożóg-Winiarska (2017) - is a critical monograph on contemporary Italian literature for young readers which emphasises the aesthetic values of those writings and their complex, multidimensional nature.

\section{Key words:}

censorship, Katarzyna Biernacka-Licznar, children's and young adult literature, Italian literature, Poland, People’s Republic of Poland, Italy, Zofia Ożóg-Winiarska

$\mathbf{J}$ ak wspomina literaturoznawczyni, italianistka i tłumaczka literatury dziecięcej Ewa Nicewicz-Staszowska (2016), wiele osób zapytanych o znajomość włoskich książek dla dzieci jest w stanie wskazać jedynie dwa XIX-wieczne dzieła - Le avventure di Pinocchio, czyli Pinokia Carla Collodiego (1883), i Cuore, a więc Serce Edmonda De Amicisa (1886) - oraz wymienić nazwisko jednego z najbardziej popularnych współczesnych pisarzy z Półwyspu Apenińskiego, Gianniego Rodariego. Zdaje się, że choć na tamtejszym rynku książki dziecięcej pojawiają się coraz to nowsze, ciekawsze publikacje, większość z nich nie trafia do Polski w ogóle lub wydawane są one w naszym języku ze znacznym opóźnieniem (Olszewska, 2017, s. 306), a niekiedy nawet w tłumaczeniu nie z oryginału, lecz z języka angielskiego. Wedle danych opublikowanych w raporcie Biblioteki Narodowej Ruch wydawniczy w liczbach, w 2018 roku w naszym kraju ukazało się 80 tłumaczeń włoskich książek dla dzieci i młodzieży (tylko o kilka więcej 
niż w roku 2017) na 1077 wszystkich przekładów literatury dla młodych czytelników z języków obcych na polski (Dawidowicz-Chymkowska, 2019, s. 72) ${ }^{1}$.

W jaki sposób można wpłynąć na popularyzację włoskiej książki dla dzieci i młodzieży na polskim rynku wydawniczym? Jednym ze sposobów na poprawę sytuacji może być uświadamianie czytelnikom i wydawcom ogromnego potencjału tamtejszej literatury dla niedorosłego czytelnika. W Polsce coraz prężniej przekonują o tym badaczki, aktywnie tłumaczące oraz analizujące włoską twórczość dziecięcą i młodzieżową, które w licznych publikacjach starają się przybliżać ją polskim odbiorcom. W ciągu ostatnich dziecięciu lat specjalistki związane ściśle ze studiami nad literaturą dziecięcą i młodzieżową, takie jak Katarzyna Biernacka-Linczar, Agnieszka Maroń, Ewa Nicewicz-Staszowska, Zofia Ożóg-Winiarska, Olga Płaszczewska, Bogumiła Staniów i Monika Woźniak, wydały kilka ważnych publikacji prezentujących „różne podejścia do zagadnienia recepcji włoskiej literatury dla dzieci i młodzieży” (Biernacka-Licznar, 2018, s. 32) i zachęcających do jej popularyzacji na polskim rynku książki. Są to m.in. artykuły i krótkie rozprawy: Włoska literatura dla dzieci i młodzieży w podręcznikach języka polskiego w szkole podstawowej (Ożóg-Winiarska, 2010), Gianni Rodari i gramatyka wyobraźni (Woźniak, 2011), O recepcji przekładowej Serca De Amicisa w Polsce (Płaszczewska, 2012), Szkice o wspótczesnych włoskich czasopismach poświęconych literaturze dziecięcej (włoska literatura dziecięca w II połowie XX wieku) (Maroń, 2015) oraz Roberto Piumini. Prolegomena do życia i twórczości pisarza (Biernacka-Licznar, Nicewicz-Staszowska, 2016), a także wieloautorski tom Przekłady w systemie małych literatur. O włosko-polskich i polsko-włoskich tłumaczeniach dla dzieci i młodzieży (Woźniak, Biernacka-Licznar, Staniów, 2014).

$\mathrm{W}$ niniejszym artykule recenzyjnym poddaję analizie dwie najnowsze monografie dotyczące włoskiej literatury dla dzieci i młodzieży oraz jej obecności na polskim rynku wydawniczym w XX i XXI wieku. Najpierw omawiam publikację późniejszą, którą jednak polecam przeczytać w pierwszej kolejności - jest to Serce Pinokia. Włoska literatura dla dzieci i młodzieży w Polsce w latach 1945-1989 autorstwa Katarzyny Biernackiej-Licznar (2018). Rozprawa ta ma charakter podręcznikowy i systematyzuje zjawiska dotyczące recepcji włoskiej literatury dla dzieci i młodzieży w Polsce, koncentrując się na latach 1945-1989 - będących okresem dynamicznych zmian politycznych

\footnotetext{
Należy zaznaczyć, że tłumaczenia włoskiej literatury dziecięcej zajęły tym samym wysokie, trzecie miejsce w całym zestawieniu, zaraz po przekładach $\mathrm{z}$ francuskiego (90 tytułów) oraz angielskiego (z którego przełożono aż 660 pozycji). Na ten temat zob. Dawidowicz-Chymkowska (2019, s. 72).
} 
w naszym kraju. Uważam, że ma ona potencjał, by w sposób uporządkowany i zwięzły dać czytelnikom (przede wszystkim tym, którzy nie są zaznajomieni z historią włoskiej literatury dla najmłodszych) podstawę do dalszych rozważań na temat kulturowego dialogu między Polską a Włochami oraz nad obecnością literatury włoskiej na naszym rynku książki. Druga praca naukowa, którą prezentuję, to Włoska literatura dla dzieci i młodzieży w zbliżeniach polskich autorstwa Zofii Ożóg-Winiarskiej (2017). Książka ta jest krytycznoliteracką monografią poświęconą współczesnej włoskiej twórczości piśmienniczej dla dzieci i koncentruje się na subiektywnie wybranych przez autorkę utworach, których głównym tematem jest dziecko i jego chęć odkrywania świata. Rozprawa może stanowić dla czytelnika ciekawe uzupełnienie pierwszej publikacji, ponieważ wykracza poza obszar badań literaturoznawczych, a także skupia się na mało znanej w Polsce włoskiej literaturze współczesnej, rzucając światło przede wszystkim na jej estetykę, potencjał interpretacyjny oraz „relacje społeczno-kulturowe” (Olszewska, 2017, s. 307) przywoływanych przez badaczkę dzieł.

Pierwsza omawiana rozprawa, czyli Serce Pinokia. Włoska literatura dla dzieci i młodzieży w Polsce w latach 1945-1989² autorstwa Katarzyny Biernackiej-Licznar (2018) - italianistki, literaturoznawczyni oraz współzałożycielki Centrum Badań Literatury dla Dzieci i Młodzieży na Uniwersytecie Wrocławskim - ukazała się nakładem Wydawnictwa Naukowego i Edukacyjnego Stowarzyszenia Bibliotekarzy Polskich jako dwunasty tom serii Literatura dla Dzieci i Młodzieży. Studia. Publikacja ta stanowi efekt systematycznych badań recepcji włoskiej literatury dziecięcej na gruncie polskim prowadzonych przez tę autorkę w ramach trzech obszarów namysłu - „historii, krytyki literatury i bibliologii” (s. 16). Opracowanie składa się ze Wstępu, sześciu rozdziałów, Zakończenia, zestawienia cytowanych tekstów oraz indeksu osobowego, a zwieńcza je Bibliografia polskich przekładów włoskich utworów dla dzieci i młodzieży w latach 1945-1989 (uzupełniona o indeksy: współtwórców, wydawców, tytułów przekładów oraz tytułów serii wydawniczych). Ta ostatnia, co warto podkreślić, stanowi wartość sama w sobie. Może bowiem stać się cennym źródłem informacji i podstawą do prowadzenia badań przez kolejnych naukowców sku-

2 Na okładce pojawiają się trzy dominujące kolory: zielony, biały oraz czerwony, a więc barwy flagi Włoch. Tytuł Serce Pinokia nosiła również poświęcona włoskiej literaturze dziecięcej w Polsce wystawa prezentowana w 2014 roku w Wojewódzkiej Bibliotece Publicznej w Krakowie (później, w 2015 roku, również w Dolnośląskiej Bibliotece Publicznej we Wrocławiu). Autorka omawianej rozprawy była współkuratorką tego wydarzenia (Biernacka-Licznar, Woźniak, Wrana, 2014). Tytuł stanowi oczywiste nawiązanie do dwóch najbardziej popularnych w Polsce włoskich książek dla dzieci: Pinokia Collodiego oraz Serca De Amicisa. 
piających się w swojej pracy badawczej na recepcji włoskiej literatury dziecięcej i młodzieżowej w naszym kraju.

Biernacka-Licznar (2018) w tym studium podjęła się analizy różnych aspektów obecności włoskich dzieł literackich dla dzieci i młodzieży, jak pisze we Wstępie, „na tle zmieniającej się dynamicznie sytuacji politycznej i społecznej w Polsce" (s. 15) w okresie niemal pół wieku, czyli, zgodnie z tytułem monografii, w latach 1945-1989 (autorce zdarza się jednak kontekstowo wykraczać poza założone ramy czasowe). Praca ta - jak dowodzi w recenzji wydawniczej Grzegorz Leszczyński (2018) - „jest pierwszym syntetycznym rozpoznaniem recepcji włoskiej literatury dziecięcej w Polsce” (czwarta strona okładki) $^{3}$. W Sercu Pinokia badaczka zaprezentowała również dane pozyskane za pomocą analizy bibliometrycznej, informacje zdobyte podczas wywiadów z tłumaczami i wydawcami oraz wyniki kwerendy w Archiwum Akt Nowych w Warszawie.

W pierwszych dwóch rozdziałach Serca Pinokia, budujących ramę teoretyczną dla kolejnych części tego opracowania, autorka wprowadza czytelników $\mathrm{w}$ problematykę monografii i w zwięzły sposób zapoznaje ich z przyjętą metodologią (są to studia nad recepcją literatury wywiedzione z koncepcji Hansa Roberta Jaussa, 1967/1999). Dokonuje również podsumowania dotychczasowego stanu badań nad obecnością w Polsce włoskich utworów dla młodych odbiorców, przywołując nie tylko najnowsze, lecz także pierwsze, przełomowe publikacje dotyczące włoskiej literatury dla dzieci i młodzieży (np. Wandy Grodzieńskiej, 1947, Heleny Grotowskiej, 1947-1948, Krystyny Kuliczkowskiej, 1947). Biernacka-Licznar (2018) zaznacza, iż jej ambicją jest „uzupełnienie oraz poszerzenie" (s. 32) pierwszej próby syntezy recepcji włoskiej literatury dziecięcej w naszym kraju w omawianym okresie, czego podjęła się kilka lat wcześniej Bogumiła Staniów (2014) w jednej z części wspomnianego już tomu Przekłady w systemie małych literatur, zatytułowanej A jednak Pinokio! O literaturze włoskiej dla dzieci w Polsce w latach 1945-2012. Kolejne segmenty rozprawy przekonują, że cel założony przez badaczkę został w pełni osiągnięty.

Trzeci rozdział został poświęcony najważniejszym tendencjom we włoskiej twórczości dla młodych czytelników od zjednoczenia krajów Półwyspu Apenińskiego w drugiej połowie XIX stulecia aż do lat osiemdziesiątych XX wieku. Stanowi on więc przegląd wydarzeń oraz procesów polityczno-społecznych zachodzących ówcześnie we Włoszech, a na tym tle autorka prezentuje kluczowe momenty rozwoju literatury dziecięcej i młodzieżowej w tym państwie,

3 Choć już wcześniej pojawiło się opracowanie Bogumiły Staniów (2014), o czym piszę w następnym akapicie. 
np. związane z publikacjami dwóch najsłynniejszych powstałych w Italii dzieł tej odmiany piśmiennictwa - Pinokia Collodiego (1883) i Serca De Amicisa (1886). Biernacka-Licznar wskazuje również na metamorfozy polityczne, które bezpośrednio oddziaływały na zmiany tendencji we włoskiej literaturze dla najmłodszych odbiorców oraz jednocześnie wpływały na popularność danych autorów i ich dzieł (np. rządy faszystowskie, kiedy to popierano pisarstwo zgodne $\mathrm{z}$ „duchem klasyczno-humanistycznym”, m.in. utwory pióra takich pisarzy jak Giuseppe Fanciulli, Salvatore Gotta i Olga Visentini, czy okres włoskiego „cudu gospodarczego", kiedy to na rynku książki dla dzieci zaczęli pojawiać się nowi twórcy, tacy jak Mario Lodi, Giovanni Arpino i Pinin Carpi).

W czwartej części Serca Pinokia pojawia się obszerne omówienie polskiego rynku literatury dziecięcej i młodzieżowej w latach 1945-1989. Rozdział ten skupia się na dokładnym uporządkowaniu informacji dotyczących wdrażania i funkcjonowania instytucji cenzury w Polsce Ludowej oraz na opisaniu działalności Głównego Urzędu Kontroli Prasy, Publikacji i Widowisk (ze szczególnym uwzględnieniem działań podejmowanych wobec książek dla niedorosłych odbiorców). Wyjątkowo interesujący dla badaczy recepcji literatury włoskiej może się okazać podrozdział na temat recenzji cenzorskich - przygotowywanych we wspomnianym wyżej Urzędzie Kontroli. Czytelnicy mogą się zapoznać z ciekawym i dotychczas rzadko omawianym materiałem badawczym, jakim są skany oryginalnych recenzji cenzorskich z Archiwum Akt Nowych w Warszawie - not poświęconych np. takim książkom, jak wspomniany wyżej Pinokio Collodiego (1883; recenzja z 1949 roku) czy Opowieść o Cebulku - Il romanzo di Cipollino - Gianniego Rodariego (1951; recenzja z 1954 roku), w których cenzorzy doceniali m.in. jakość tłumaczenia i przekładu oraz dowcipność i przystępność omawianych dzieł. Mimo iż ostatecznie materiał okazał się zbyt skromny i wybiórczy, aby wysnuć na jego podstawie szersze wnioski, jego analiza pozwoliła autorce na „zorientowanie się w praktykach cenzorskich” (Biernacka-Licznar, 2018, s. 58), które funkcjonowały w ówczesnym, PRL-owskim systemie wydawniczym, i w wartościach, które były wtedy oficjalnie wyznawane oraz szerzone.

Kontynuacją tego wątku jest rozdział piąty, poświęcony w całości recepcji wydawniczej włoskiej literatury dziecięcej i młodzieżowej w Polsce w okresie PRL-u. Autorka postawiła sobie za zadanie odpowiedzieć m.in. na następujące pytania: „Jak kształtowała się wielkość produkcji przekładów z języka włoskiego na tle ówczesnej produkcji dla dzieci i młodzieży? Jakimi kryteriami kierowano się przy doborze tytułów do tłumaczenia? Kim byli tłumacze odpowiedzialni za przybliżenie włoskiej literatury dzieciom i młodzieży?" (Biernacka-Licznar, 2018, s. 80). Dokładne analizy, tabele i mapowania 
literaturoznawczyni skonstruowała na podstawie wielu cennych źródeł, np. katalogów bibliotecznych oraz wywiadów z żyjącymi jeszcze tłumaczami i redaktorami działającymi w badanym przez nią przedziale czasowym, jak również dokumentów Głównego Urzędu Statystycznego czy też analiz rozwoju ilościowego polskich ruchów wydawniczych. Dzięki skrupulatnemu zestawieniu zdobytych danych badaczka była w stanie nakreślić, jak wyglądała produkcja wydawnicza przekładów włoskich książek dla dzieci i młodzieży w okresie Polski Ludowej, a także wskazać, jacy autorzy byli wtedy - i w którym momencie w historii PRL-u - najbardziej popularni. Wyróżniła również szczególnie aktywnych ówcześnie translatorów, wśród których zwłaszcza tłumaczki działające w Warszawie (m.in. Zofia Ernstowa, Wanda Gall, Krystyna Kabatcowa, Olga Nowakowska) znacznie przyczyniły się do popularyzacji na rodzimym gruncie włoskiej literatury dla dzieci i młodzieży.

Szósty, najobszerniejszy rozdział książki poświęcony został miejscu literackiej twórczości wybranych włoskich autorów w Polsce w latach 1945-1989. Badaczka zdecydowała się na omówienie poszczególnych pisarzy i ich dzieł w osobnych podrozdziałach, wedle kolejności pojawiania się przekładów książek na naszym rynku wydawniczym. Zaczyna więc od Serca De Amicisa (1886), którego pierwsza powojenna edycja ukazała się już w 1945 roku, a następnie rozpatruje odbiór twórczości takich autorów jak m.in. już przywołani Collodi i Rodari, Italo Calvino, Rossana Guarnieri, Alberto Manzi, Bianca Pitzorno, Antonio Gramsci czy Paolo Statuti. W każdym haśle Biernacka-Licznar prezentuje krótką biografię oraz podsumowanie twórczości danego autora bądź danej autorki, jak również przywołuje jego/jej najistotniejsze dzieła i szczegółowo opisuje recepcję konkretnych utworów w Polsce Ludowej. Rozdział ten został uzupełniony o grafiki i okładki wybranych polskich wydań omawianych książek, co zdecydowanie dopełnia obraz recepcji włoskich dzieł dla dzieci i młodzieży w konkretnym okresie, jak również wskazuje na tendencje i style dominujące $\mathrm{w}$ dawnej polskiej ilustracji książkowej dla dzieci i młodzieży. W zakończeniu monografii autorka dokonuje krótkiego podsumowania badań, podkreślając przy tym, iż w okresie 1945-1989 „niemały wpływ na recepcję literatury miała struktura ówczesnego ruchu wydawniczego" (Biernacka-Licznar, 2018, s. 243) oraz rola Instytutu Wydawniczego „Nasza Księgarnia”, który starał się jak najczęściej publikować przekłady z literatur zachodnich.

Monografia Biernackiej-Licznar, rozpatrywana jako całość, stanowi bogate źródło wiedzy na temat nie tylko włoskich dzieł literatury dziecięcej i młodzieżowej, lecz także złożonej struktury i rozmaitych mechanizmów funkcjonowania polskiego rynku wydawniczego w czasach PRL-u (w tym - zasad działania ówczesnej cenzury). Na pochwałę zasługuje zarówno treść pracy, 
oparta na ciekawych źródłach, jakimi są m.in. przeprowadzone przez autorkę wywiady oraz badania archiwalne, jak i bardzo przejrzysta struktura oraz wspomniana już, wieńcząca monografię Bibliografia polskich przekładów włoskich utworów dla dzieci i młodzieży w latach 1945-1989, która z pewnością okaże się pomocna dla wielu badaczy włoskiej literatury dziecięcej i młodzieżowej.

Bardziej krytycznoliteracka i subiektywna (m.in. pod względem doboru materiału badawczego) jest wcześniejsza o rok, ale dotycząca nowszych zjawisk publikacja na temat obecności włoskiej literatury dla młodych odbiorców w Polsce, czyli Włoska literatura dla dzieci i młodzieży w zbliżeniach polskich autorstwa Zofii Ożóg-Winiarskiej (2017) - profesor Uniwersytetu Jana Kochanowskiego w Kielcach oraz autorki licznych przekładów z włoskiego i prac naukowych dotyczących twórczości dla niedorosłych czytelników. Opracowanie to jest „monograficznym zarysem współczesnej literatury włoskiej dla młodych czytelników” (s. 7), skompilowanym wszakże z „samowystarczalnych”, osobnych artykułów napisanych przez badaczkę (i niekiedy wcześniej już opublikowanych w czasopismach i tomach zbiorowych) na przestrzeni kilku lat. Rozprawa, oprócz Słowa wstępnego, bibliografii oraz indeksu nazwisk składa się z jedenastu rozdziałów interpretacyjnych, w których Ożóg-Winiarska omawia twórczość wybranych włoskich autorów i autorek literatury dla dzieci i młodzieży (takich jak np. Pinin Carpi, Paolo Statuti, Bianca Pitzorno, Angela Nanetti, Roberto Piumini, Guido Quarzo czy Beatrice Masini), rozdziału dwunastego, poświęconego twórczości plastycznej Agnieszki Kiełkiewicz i ilustracjom tej artystki do Pinokia, a także trzynastego, cennego rozdziału dotyczącego recepcji włoskiej literatury dla dzieci i młodzieży w podręcznikach języka polskiego w szkole podstawowej. Na końcu opracowania pojawia się dodatek w postaci przetłumaczonych przez autorkę na język polski utworów Paola Statutiego. Każdemu z rozdziałów towarzyszą podsumowania w języku angielskim i włoskim.

Monografia w dużej mierze bazuje na kompetentnych i wartościowych analizach, w ramach których badaczka stara się zaprezentować czytelnikom ogromny potencjał interpretacyjny wybranych dzieł włoskiej literatury dla młodych odbiorców. Włoska literatura dla dzieci i młodzieży w zbliżeniach polskich, jak pisze Ożóg-Winiarska (2017), ma bowiem za zadanie zaprezentować odbiorcom „szersze spojrzenie na utwory włoskiej literatury dla najmłodszych, wydawane u nas w różnych okresach i niejako "rozproszone" w recepcji wydawniczej i niemal nieobecne w opracowaniach badawczych" (s. 7). Zebrane $\mathrm{w}$ tomie teksty, według autorki opracowania, mają przede wszystkim inspirować: po pierwsze, polskiego rodzica i nauczyciela - do bliższego zapoznania 
dziecka z magicznym światem włoskiej książki; po drugie, badacza - do zagłębiania się w „unikalną estetykę” włoskiej literatury; po trzecie zaś, wydawcę - do poszerzania obecności włoskiej literatury dziecięcej i młodzieżowej na polskim rynku wydawniczym i dokonywania jej częstszych przedruków (s. 8). Publikacja, jak podkreśla sama badaczka, „zbliża się metodologicznie do antropologii kulturowej” (s. 8) - znaleźć w niej można zatem wiele odniesień do kultury współczesnej i filozofii, a także rozległe rozważania np. o dzieciństwie $\mathrm{w}$ różnych jego aspektach, o potrzebach dziecka i o jego pozycji w społeczeństwie oraz, szerzej, w świecie (wykracza zatem poza tradycyjnie rozumianą naukę o literaturze).

Ożóg-Winiarska zwraca ogromną uwagę na estetykę włoskiej literatury dziecięcej, na jej wielowymiarowość oraz siłę oddziaływania na wyobraźnię. Autorka w swoich rozważaniach często koncentruje się na popularnych w literaturze dziecięcej - nie tylko tej z Półwyspu Apenińskiego - symbolach bądź też motywach, takich jak chociażby choinka, kot, drzewo, podróż itp. Prezentuje sposób ich opracowania przez włoskich autorów literatury dla najmłodszych odbiorców, ujawniając specyfikę tych ujęć poprzez m.in. porównywanie omawianych utworów do światowej klasyki (np. dzieł Hansa Christiana Andersena). Nie brakuje tu również ciekawych propozycji z zakresu badań komparatystycznych: Ożóg-Winiarska dokonuje bezpośrednich analiz porównawczych, zestawiając włoskie utwory dla niedorosłych czytelników z polską literaturą dziecięcą (np. twórczość Pinina Carpiego z dziełami Józefa Ratajczaka) oraz szukając wspólnych im symboli i wartości.

Autorce udaje się ukazać w monografii włoskie utwory dla dzieci jako dzieła poświęcone uniwersalnym, ponadkulturowym znakom; jako teksty, w których każde dziecko i każdy dorosły będzie w stanie znaleźć coś inspirującego oraz fascynującego. Według Ożóg-Winiarskiej (2017) to właśnie „bogactwo i zróżnicowanie" (s. 8) włoskiej literatury dla najmłodszych stanowi o jej wyjątkowości - ta twórczość w proponowanym w tomie ujęciu ma niezwykłe możliwości w zakresie łączenia realizmu i magii, awangardy i tradycji, oraz organizuje masową wyobraźnię. Kolejnym, bardzo ważnym spoiwem omawianych przez autorkę włoskich tekstów jest dziecko będące centrum narracji - przedstawiane jako część grupy społecznej współtworzącej przedstawiane $\mathrm{w}$ danej historii wydarzenia, a nie jedynie jako ich bierny odbiorca. Przykłady aktywnych bohaterów i bohaterek znajdziemy w większości przywołanych w rozprawie dzieł włoskiej literatury dziecięcej i młodzieżowej. Autorka pisze o takich postaciach m.in. w rozdziałach o transgresywnych i eksploratywnych tekstach Gianniego Rodariego (rozdział pierwszy), o dziełach Mario Lodiego, który łączył motywy baśniowe ze współczesną kulturą masową 
i rzeczywistością społeczną, aby przekazywać dzieciom praktyczne mądrości i zachęcać je do wspólnego, aktywnego przeciwdziałania złu (rozdział trzeci), o przygodach bohaterek prozy Bianki Pitzorno i ich „ponaddziecięcym” wymiarze, mającym na celu przedstawienie magicznej rzeczywistości z dala od stereotypów i podziałów społecznych (rozdział szósty), o serii książek Ładne, sprytne i odważne (Belle, astute e coraggiose) autorstwa Beatrice Masini (poszczególne części zostały opublikowane w Polsce w latach 2011-2012), która nadając dorosłemu życiu dziecięce aspekty, uczy młodych ludzi wrażliwości na dobro i piękno (rozdział jedenasty).

W publikacji znalazło się również miejsce na słynnego Pinokia. W rozdziale dwunastym autorka dokonuje bowiem analizy ilustracji stworzonych do tej powieści przez artystkę z Piotrkowa Trybunalskiego - Agnieszkę Kiełkiewicz. Ożóg-Winiarska docenia przede wszystkim grę kolorów stosowaną prze ilustratorkę, a także próbuje odkryć przed czytelnikiem znaczenie stosowanej przez Kiełkiewicz perspektywy oraz symboliki. Za główną cechę ilustracji piotrkowskiej artystki autorka uznaje przedstawianie Pinokia jako „beztroskiego, rozmarzonego, lirycznego chłopca”, co według niej świadczy o niezwykłej dojrzałości graficzki oraz o jej „dobrej znajomości psychiki dziecięcej” (Ożóg-Winiarska, 2017, s. 220). Ostatni, trzynasty rozdział publikacji ma natomiast nieco inny charakter: jest to krótkie omówienie miejsca włoskiej literatury dla dzieci i młodzieży w podręcznikach języka polskiego w szkołach podstawowych. Autorka podkreśla w tym studium ciągłą obecność dwóch najbardziej popularnych włoskich dzieł literatury dziecięcej - Pinokia i Serca - w owych podręcznikach, wskazując przy tym na wybierane przez wydawców fragmenty oraz analizując proponowany przez autorów owych opracowań sposób pracy z tymi tekstami. Co istotne, podkreśla także brak współczesnych włoskich utworów w szkolnych podręcznikach (wymieniając jako warte większej uwagi dzieła takich autorów jak Teresa Buongiorno, Pinin Carpi czy Roberto Piumini).

Włoska literatura dla dzieci i młodzieży $w$ zbliżeniach polskich to publikacja interdyscyplinarna, wybiegająca poza ramy literaturoznawstwa, a opierająca się w dużej mierze na semiotyce, antropologii kulturowej oraz filozofii. Zebrane w niej teksty odkrywają przed czytelnikiem świat symboli i wartości różnych utworów współczesnej włoskiej literatury dziecięcej, porównywanych przy tym do innych polskich i światowych dzieł artystycznych. Intertekstualna mozaika przedstawiona w książce, moim zdaniem, jest bardzo ciekawa i mimo wszystko spójna - całość dobrze oddaje ogromny potencjał interpretacyjny współczesnych włoskich dzieł dla dzieci, wskazując przy tym na popularne wśród wybranych autorów motywy i symbole. Badaczce udaje się osiągnąć założony cel - teksty zebrane w tomie, jak sądzę, mogą zachęcić wielu 
czytelników (rodziców, badaczy, nauczycieli) do zapoznania się z omówionymi przez autorkę utworami oraz pomogą w dobraniu odpowiednich tekstów do potrzeb najmłodszych. Dużym atutem publikacji jest załączony appendix, w którym świetnie znająca język włoski Ożóg-Winiarska zamieściła własne przekłady utworów Paolo Statutiego, wciąż rzadko tłumaczonego na język polski.

Zaprezentowane w artykule ważne publikacje dotyczące włoskiej literatury dla dzieci i młodzieży oraz jej recepcji na gruncie polskim w XX i XXI wieku ukazują dwa odmienne podejścia badawcze. Pierwsza z nich, Serce Pinokia. Włoska literatura dla dzieci i młodzieży w Polsce w latach 1945-1989 autorstwa Katarzyny Biernackiej-Licznar (2018), stanowi podsumowanie badań, wywiadów i analiz autorki nad recepcją włoskiej literatury dla dzieci i młodzieży w Polsce w konkretnych ramach czasowych, tzn. w okresie 1945-1989. Druga publikacja, Włoska literatura dla dzieci i młodzieży w zbliżeniach polskich Zofii Ożóg-Winiarskiej (2017), jest natomiast zbiorem krytycznoliterackich artykułów poświęconych współczesnej włoskiej literaturze dla dzieci i młodzieży, w których autorka zachęca czytelników do zwrócenia uwagi na zróżnicowany charakter powstałych w Italii dzieł dla dzieci, na ich ogromny potencjał interpretacyjny oraz wyjątkową estetykę. Obie prace, uzupełniając się, stanowią ważne źródło wiedzy na temat stanu recepcji włoskiej literatury dziecięcej i młodzieżowej w Polsce od roku 1945 po współczesność, jak również zachęcają do poszerzania obecności owej literatury na polskim rynku wydawniczym.

\section{Bibliografia}

Biernacka-Licznar, K. (2018). Serce Pinokia. Włoska literatura dla dzieci i młodzieży $w$ Polsce w latach 1945-1989. Warszawa: Wydawnictwo Naukowe i Edukacyjne SBP.

Biernacka-Licznar, K., Nicewicz-Staszowska, E. (2016). Roberto Piumini. Prolegomena do życia i twórczości pisarza. Bibliotheca Nostra, 1(43), 26-41.

Biernacka-Licznar, K., Woźniak, M., Wrana, M. (2014). Serce Pinokia. Włoska literatura dziecięca w Polsce [katalog wystawy]. Kraków: Włoski Instytut Kultury.

Collodi, C. (1883). Le avventure di Pinocchio. Storia di un burattino. Firenze: Felice Paggi.

Dawidowicz-Chymkowska, O. (oprac.). (2019). Tabl. 12. Tłumaczenia na język polski (według typów). Ruch Wydawniczy w Liczbach, 67, 72.

De Amicis, E. (1886). Cuore. Milano: Fratelli Treves.

Grodzieńska, W. (1947). Trzy przekłady książek dla dzieci. Kuźnica, 50, 10. 
Grotowska, H. (1947-1948). Literatura dla dzieci i młodzieży we Włoszech w latach ostatnich. Ruch Pedagogiczny, 31(9-10), 31-43.

Jauss, H. R. (1999). Historia literatury jako prowokacja (M. Łukasiewicz, tłum.). Warszawa: Wydawnictwo IBL PAN. (wyd. oryg. 1967).

Kuliczkowska, K. (1947). Wśród klasyków literatury dziecięcej. Odrodzenie, 31(140), 7.

Leszczyński, G. (2018). b.t. [fragment recenzji wydawniczej]. W: K. Biernacka-Licznar, Serce Pinokia. Włoska literatura dla dzieci i młodzieży w Polsce w latach 1945-1989 (czwarta strona okładki). Warszawa: Wydawnictwo Naukowe i Edukacyjne SBP.

Maroń, A. (2015). Szkice o współczesnych włoskich czasopismach poświęconych literaturze dziecięcej (włoska literatura dziecięca w II połowie XX wieku). Annales Universitatis Paedagogicae Cracoviensis. Studia ad Bibliothecarum Scientiam Pertinentia, 13, 263-281.

Nicewicz-Staszowska, E. (2016). Dziesięć włoskich książek (nie tylko) dla dzieci. Lente. Pobrane z: https://lente-magazyn.com/dziesiec-wloskich-ksiazek-nie-tylko-dladzieci-lente/.

Olszewska, B. (2017). Wyobraźnia bez granic, czyli co nowego w literaturze włoskiej. Studia Filologiczne Uniwersytetu Jana Kochanowskiego, 30, 305-310.

Ożóg-Winiarska, Z. (2010). Włoska literatura dla dzieci i młodzieży w podręcznikach języka polskiego w szkole podstawowej. Studia Filologiczne Uniwersytetu Humanistyczno-Przyrodniczego Jana Kochanowskiego, 23, 79-90.

Ożóg-Winiarska, Z. (2017). Włoska literatura dla dzieci i młodzieży w zbliżeniach polskich. Kielce: Instytut Filologii Polskiej UJK.

Płaszczewska, O. (2012). O recepcji przekładowej Serca De Amicisa w Polsce. Italica Wratislaviensia, 3, 85-106.

Rodari, G. (1951). Il romanzo di Cipollino. Roma: Edizioni di Cultura Sociale.

Staniów, B. (2014). A jednak Pinokio! O literaturze włoskiej dla dzieci w Polsce w latach 1945-2012. W: M. Woźniak, K. Biernacka-Linczar, B. Staniów, Przekłady w systemie małych literatur. O włosko-polskich i polsko-włoskich tłumaczeniach dla dzieci i młodzieży (s. 228-268). Toruń: Adam Marszałek.

Woźniak, M. (2011). Gianni Rodari i gramatyka wyobraźni. W: G. Rodari, Niewidzialny Tonino (E. Nicewicz, tłum., s. 71-79). Kraków: Bona.

Woźniak, M., Biernacka-Linczar, K., Staniów, B. (2014). Przekłady w systemie małych literatur. O włosko-polskich i polsko-włoskich tłumaczeniach dla dzieci i młodzieży. Toruń: Adam Marszałek. 